\title{
DIEBACK, LEAF AREA INDEX AND YIELD OF YOUNG EUCALYPT CLONES PLANTATION IN THE BRAZILIAN SAVANNAH REGION ${ }^{1}$
}

\author{
Geraldo Gonçalves dos Reis ${ }^{2 *}$, Frederico de Freitas Alves ${ }^{3}$, Maria das Graças Ferreira Reis ${ }^{2}$, Felippe
}

Coelho de Souza ${ }^{4}$, Diogo Sena Baiero ${ }^{3}$, Filipe Valadão Cacau ${ }^{3}$ and Ronan Soares de Faria ${ }^{3}$

\footnotetext{
${ }^{1}$ Received on 09.06.2016 accepted for publication on 24.03.2017.

${ }^{2}$ Universidade Federal de Viçosa, Departamento de Engenharia Florestal, Viçosa, Minas Gerais, Brasil. E-mail: < greis@ufv.br $>$ and $<$ mgfreis@ufv.br $>$.

${ }^{3}$ Universidade Federal de Viçosa, Programa de Pós-Graduação em Ciência Florestal, Viçosa, Minas Gerais, Brasil. E-mail: <fredfa2003@yahoo.com.br>,<dsbaiero@ufv.br>,<ronan.faria@ufv.br>and<filipecacau@gmail.com>.

${ }^{4}$ Universidade Federal de Viçosa, Doutorado em Ciência Florestal, Viçosa, Minas Gerais, Brasil. E-mail: <felippe.souza@ufv.br>. *Corresponding author.
}

\begin{abstract}
Eucalypt has been widely planted in Brazil, in the savannah region, which is characterized by high soil water deficit and low fertility. Dieback, leaf area index (LAI) and yield of young stands of 16 eucalypt

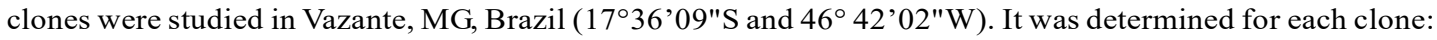
a) the proportion of the tree height with dieback symptoms in the apical terminal (HWD\%) and the proportion of trees with dieback (NWD\%), at 13 months (end of the first dry season); b) the LAI at 13 and 21 months, and c) the yield at the age of 13, 19 and 25 months. HWD\% reached 5-9\%, and NWD\%, 50-80\%, for the five most susceptible clones, when the soil water deficit reached $508 \mathrm{~mm}$ in the year. LAI varied from 0.61 to 1.56 , at 13 months, and from 2.31 to 3.48 at 21 months, presenting inverse relationship with dieback. The least susceptible clones to dieback achieved the highest yield up to 25 months of age. There was interaction between dieback and fertilizer levels only for three clones. There was a positive correlation $(\mathrm{p} \leq 0.001)$ between the LAI at the age of 13 months and the periodic monthly increment from 0 to 11 months, and from 11 to 19 months. The difference in dieback susceptibility among clones allows the selection of genotypes for regions where the soil water deficit is a major limiting factor.
\end{abstract}

Keywords: Dieback susceptibility; Abiotic damage; Drought resistance

\section{SECA DE PONTEIROS, ÍNDICE DE AREA FOLIAR E PRODUÇÃO DE CLONES DE EUCALIPTO NA REGIÃO DE CERRADO}

RESUMO - Eucalipto tem sido plantado, no Brasil, na região de cerrado, caracterizado por elevado défice hídrico no solo e baixa fertilidade. A seca de ponteiros, o indice de área foliar (IAF) e a produção de povoamentos

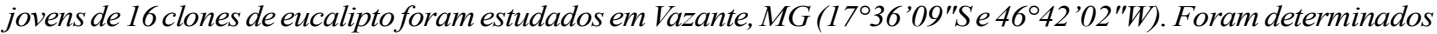
para cada clone: a) a proporção da altura da árvore com sintomas de seca de ponteiro (HWD\%) e a proporção de plantas com seca de ponteiros (NWD\%), aos 13 meses (final da primeira estação seca); b) o IAF, aos 13 e 21 meses e, c) a produção de cada clone aos 13, 19 e 25 meses de idade. HWD\% atingiu 5-9\%, e $N W D \%, 50-80 \%$, para cinco clones mais susceptiveis, tendo ocorrido défice hídrico de $508 \mathrm{~mm}$ no ano. $O$ IAF variou de 0.61 a 1.56, aos 13 meses, e de 2.31 a 3.48 aos 21 meses de idade, apresentando relação inversa com a seca de ponteiros. Os clones menos susceptíveis exibiram elevada produção até 25 meses de idade. Houve correlação positiva ( $p \leq 0.001)$ entre o IAF aos 13 meses e o incremento periódico mensal entre 0 e 11 meses e entre 11 e 19 meses de idade. A susceptibilidade diferenciada à seca de ponteiros entre clones permite a seleção de genótipos para regiões com deficiência hídrica no solo.

Palavras-Chave: Susceptibilidade à seca de ponteiros; Dano abiótico; Resistência à seca 


\section{INTRODUCTION}

The eucalypt plantations are spread over the Brazilian savannah region, characterized by soils with low fertility and low moisture retention capacity, and irregular rainfall distribution throughout the year. Those conditions could favor the occurrence of a gradual dying of the young shoots starting at the tips (dieback). Depending on the dieback intensity there may be plant death or just leaf area reduction and loss of apical dominance (Ferreira, 1989) with subsequent recovery after re-watering (Chaves et al., 2004). After dieback, there is a reduction of the apical dominance and several epicormic branches arise (Oliva et al., 1989), leading to bifurcation of the trunk with consequent reduction in wood quality. The severity of the dieback on tree species may vary with the genotype (Cipriani et al., 2012; Andrade, 2013), soil water deficit (Ferreira, 1989; Oliva et al., 1989; Maschio et al., 2000; Chaves et al., 2004; Linares and Camarero, 2012; Almeida et al., 2013), nutrients, especially boron deficiency (Mattiello et al., 2009), soil water-logging, as reported for the Rio Doce region, Brazil (Harguindeguy, 2013; Leite et al., 2014), diseases (Coutinho et al., 2002; Arriel et al., 2014), among others.

The effect of dieback in forest productivity can be evaluated through the analysis of canopy structure, which includes the determination of leaf area index (LAI) and leaf distribution along the crown. LAI measurement in an age sequence may highlight changes in the canopy (Lima, 2003; Whitehead and Beadle, 2004; Xavier et al., 2002; Oliveira et al., 2008) and help explaining the cause-effect of the dieback. LAI can be used to indicate the interception capacity of photosynthetically active radiation, which affects forest productivity (Lang and Mcmurtrie, 1992). The LAI varies with the genotype, plant age, environmental conditions and management methods, among others (Xavier et al., 2002; Lima, 2003; Chaves et al., 2007; Fontan, 2007; Oliveira et al., 2016). For example, in sites with adequate availability of nutrients and water in the soil, the LAI is higher than in sites with limited resources (Whitehead and Beadle, 2004).

The high demand for forest products and the need to reach economic sustainability has encouraged forest companies to aim for high productivity eucalypt plantations. This can be attained with the adoption of adequate management techniques associated with the use of genotypes selected for specific sites (Gonçalves et al., 2004; Santos et al., 2015). The productivity of planted forest depends on the photosynthetic efficiency, and, consequently, on leaf area, and light use efficiency (Wong and Dunin, 1987; Whitehead and Beadle, 2004; Broeckx et al., 2015), and on the availability of nutrients and water in the soil (Barros et al., 2000; Binkley et al., 2004; Stape et al., 2004, 2010). Soil moisture and root growth, among others, vary with genotype and stand management, and interfere on the availability and acquisition of nutrients (Reis and Hall, 1987; Reis et al., 2006; Leles et al., 1998; Bouillet et al., 2002; Mattiello et al., 2009). Thus, it is not enough that the nutrients are present in the soil, but also there must be adequate soil and plant conditions allowing their acquisition by trees. Finally, if the health of the forest is not satisfactory to produce high yield, studies should be undertaken to help elucidate the causes of yield loss.

This study aimed to evaluate the dieback, leaf area index and yield of eucalypt clones plantation and, its relationship with soil water availability and nutrients, in the savannah region, in Brazil.

\section{MATERIALAND METHODS}

This study was undertaken with 16 eucalypt clones and six fertilizer levels, in the split plot design, with the clones in the plots and the fertilizer levels in the subplots, with six replications and 10 plants in the experimental unit. Planting was carried out in October, 2006 , in the arrangement of $3.6 \times 2.5 \mathrm{~m}$ in the area of Votorantim Siderurgia Ltda. (VS) in the municipality of Vazante, Minas Gerais ( $17^{\circ} 36^{\prime}$ S, $46^{\circ} 42^{\prime}$ W and average altitude of $550 \mathrm{~m}$ ) in the savannah region. The soils in the region are classified as Oxisol. The proportion of clay in the soil of the experimental area is $33.5 \%$, with $34.5 \%$ of coarse sand and $22.5 \%$ of fine sand to the depth of $40 \mathrm{~cm}$, and it is classified as sand clay loam, i.e., a well-drained soil. Monthly rainfall and soil water deficit based on Thornthwaite water balance, for the study period, are presented in Table 1.

The clones studied were: E1, E2, E4, E5, E6, 19, 157 and GG100 (Eucalyptus urophylla $\mathrm{x}$ Eucalyptus grandis artificial hybrids); 2, 3487 and I042 (Eucalyptus urophylla); 10, 36, 62 and 280 (Eucalyptus camaldulensis) and, 58 (artificial hybrid of E. camaldulensis $\mathrm{x}$ E. grandis).

Revista Árvore. 2017;41(3):e410309 
Table 1 - Monthly rainfall (P) between October 2006 and November 2008, and soil water deficit (SWD) based on Thornthwaite water balance, for the studied area.

Tabela 1 - Precipitação mensal (P) entre outubro de 2006 e novembro de 2008, e défice hídrico (SWD) com base no balanço hídrico de Thornthwaite, para a área de estudo.

\begin{tabular}{|c|c|c|c|c|c|c|}
\hline \multirow[b]{2}{*}{ Month } & \multicolumn{2}{|c|}{2006} & \multicolumn{2}{|c|}{2007} & \multicolumn{2}{|c|}{2008} \\
\hline & $\mathrm{P}(\mathrm{mm})$ & $\mathrm{SWD}(\mathrm{mm})$ & $\mathrm{P}(\mathrm{mm})$ & $\mathrm{SWD}(\mathrm{mm})$ & $\mathrm{P}(\mathrm{mm})$ & $\mathrm{SWD}(\mathrm{mm})$ \\
\hline Jan & 120,00 & 0,00 & 399,00 & 0,00 & 312,00 & 0,00 \\
\hline Feb & 26,50 & 25,18 & 141,90 & 0,00 & 380,00 & 0,00 \\
\hline Mar & 188,50 & 0,00 & 25,00 & 26,48 & 217,00 & 0,00 \\
\hline Apr & 89,00 & 0,10 & 43,00 & 32,98 & 5,00 & 29,18 \\
\hline May & 0,00 & 19,05 & 5,00 & 53,36 & 0,00 & 47,41 \\
\hline June & 0,00 & 31,29 & 0,00 & 51,44 & 0,00 & 49,91 \\
\hline July & 0,50 & 42,45 & 0,00 & 61,04 & 0,00 & 47,90 \\
\hline Aug & 12,00 & 60,51 & 0,00 & 67,55 & 0,00 & 76,43 \\
\hline Sept & 47,50 & 42,67 & 0,00 & 97,04 & 40,00 & 62,28 \\
\hline Oct & 246,00 & 0,00 & 17,00 & 118,54 & 0,00 & 141,81 \\
\hline Nov & 344,50 & 0,00 & 128,00 & 0,00 & 129,50 & 0,00 \\
\hline Dec & 456,50 & 0,00 & 188,00 & 0,00 & 158,00 & 0,00 \\
\hline Total & 1531,00 & 221,25 & 946,90 & 508,43 & 1241,50 & 454,91 \\
\hline
\end{tabular}

The soil preparation consisted of sub-soil ripped to $50-60 \mathrm{~cm}$ depth with simultaneous addition of reactive rock phosphate $\left(360 \mathrm{~g} \mathrm{plant}^{-1}\right)$, for all treatments. Dolomitic limestone zincal (fineness rate $>85 \%$ ) was applied in total area $\left(4 \mathrm{tha}^{-1}\right)$. The NPK fertilizer (1028-06) was applied immediately after planting, with the doses: 0 (control), 78, 100, 130, 156 and 234 g plant $^{-}$ 1 , at two opposite points about $15 \mathrm{~cm}$ away from the seedlings, using a hand fertilizer machine. The dose of $78 \mathrm{~g} \mathrm{plant}^{-1}$ was recommended for the area based on the NUTRICALC program, a simulation model that enables to formulate fertilizer recommendations for eucalypt plantations, taking into account the management adopted in these plantations (Barros et al., 2000). Doses of 100 and $130 \mathrm{~g} \mathrm{plant}^{-1}$ of NPK 10-28-06 were, at that time, empirically used in commercial plantations by the company and, 156 and $234 \mathrm{~g} \mathrm{plant}^{-1}$ corresponded to two and three times the recommended fertilizer by using NUTRICALC. At the age of three months, it was applied $20 \mathrm{~g} \mathrm{plant}^{-1}$ of borogram $(10 \% \mathrm{~B})$ in a circle on the surface, and $169 \mathrm{~g} \mathrm{plant}^{-1}$ of NPK 20-0-20 in each side of the plant. Borogram application was repeated three months later.

The eucalypt dieback was evaluated 13 months after planting (November 2007), at the end of the first dry period. Dieback was characterized by wilting and subsequent loss of the leaves of the upper canopy, ending with the death of that portion of the plant. The height of the canopy affected by dieback was evaluated for 10 plants in each plot to obtain the proportion of the height with dieback symptoms (HWD\%) and the percentage of trees showing any symptoms of dieback (NWD\%), to assist in evaluating the susceptibility of clones.

The LAI was measured at 13 (November 2007) and 21 (July 2008) months, at one point per plot between the first and the second plant in the row, in three replications. Two LI-2050 sensors connected to the LI-2000 datalogger, both from LI-COR brand, were used for measurements in an open area next to the stand and inside the plots. The readings were taken in diffuse light at dawn and dusk, and or on cloudy days.

The diameter at $1.30 \mathrm{~m}$ height $(\mathrm{DBH})$ and total height (Ht) of 10 trees in each experimental unit were measured at 11,19 and 25 months of age.

Inventory data held by the company for commercial plantations of GG100, I042, 19, 58, 62 and 2 clones were used to estimate the volume equations for individual trees, from the Schumacher and Hall model in a nonlinear model, for each of these six clones. A general equation was adjusted for the other clones that did not exist in commercial plantations, using the data set of the six clones. Periodic monthly increment (PMI) $\left(\mathrm{m}^{3} \mathrm{ha}^{-1}\right.$ month $\left.{ }^{-1}\right)$, representing the change in yield in a growth period, was obtained for each clone for the periods of 0-11, 11-19 and 19-25 months of age.

Revista Árvore. 2017;41(3):e410309 
The occurrence of dieback, LAI and yield for each clone were analyzed by the $\mathrm{F}$ test, at $95 \%$ probability. When there was difference $(\mathrm{p} \leq 0.05)$, it was applied the Tukey and Scott Knott test, at 95\% probability. The correlation analysis was performed at $95 \%$ probability, between the PMI and the LAI. Whenever it was required, the data was transformed to meet the statistical assumptions.

\section{RESULTS}

The proportion of total tree height with dieback $($ HWD $\%)$ varied $(\mathrm{p} \leq 0.05)$ among clones and fertilizer levels and, there was interaction between three clones

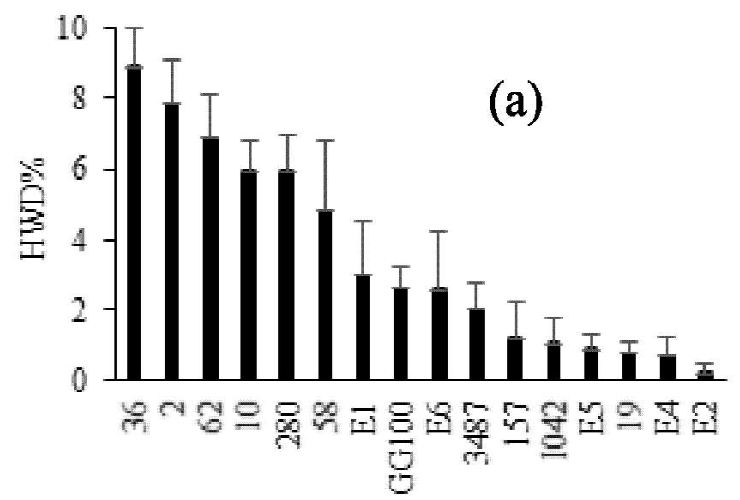

Clone

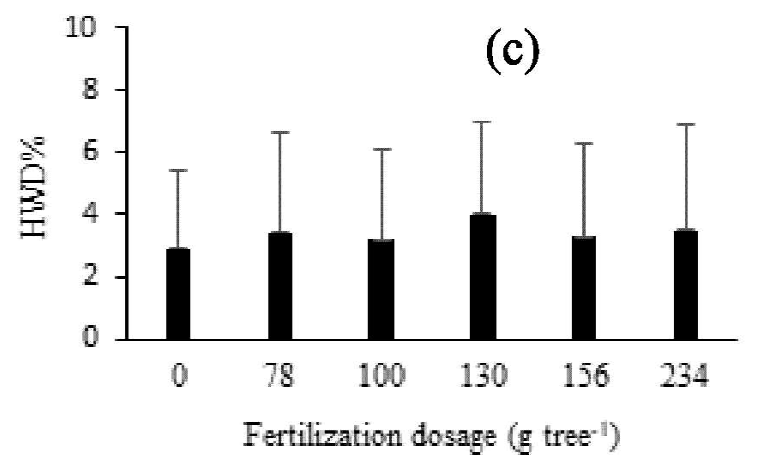

and fertilizer. The eucalypt clone 36 presented the highest intensity of dieback with HWD $\%$ of $8.85 \%$, and $80 \%$ of the trees with some crown damage. The dieback was also severe for the clones 2, 10, 62, 280 and 58 (Figure 1a, b). The clones E2, E4, 19, E5, I042 and 157 showed reduced HWD \% and NWD\%. The E2 clone showed only 3.33\% of the trees with the symptom and $0.22 \%$ of the height of the canopy compromised by dieback.

There was lower incidence of dieback for all clones when only rock phosphate was applied (Figure 1c, d).

The interaction clone $\mathrm{x}$ fertilizer levels in relation to the HWD \% was significant $(\mathrm{p} \leq 0.05)$ only for clones
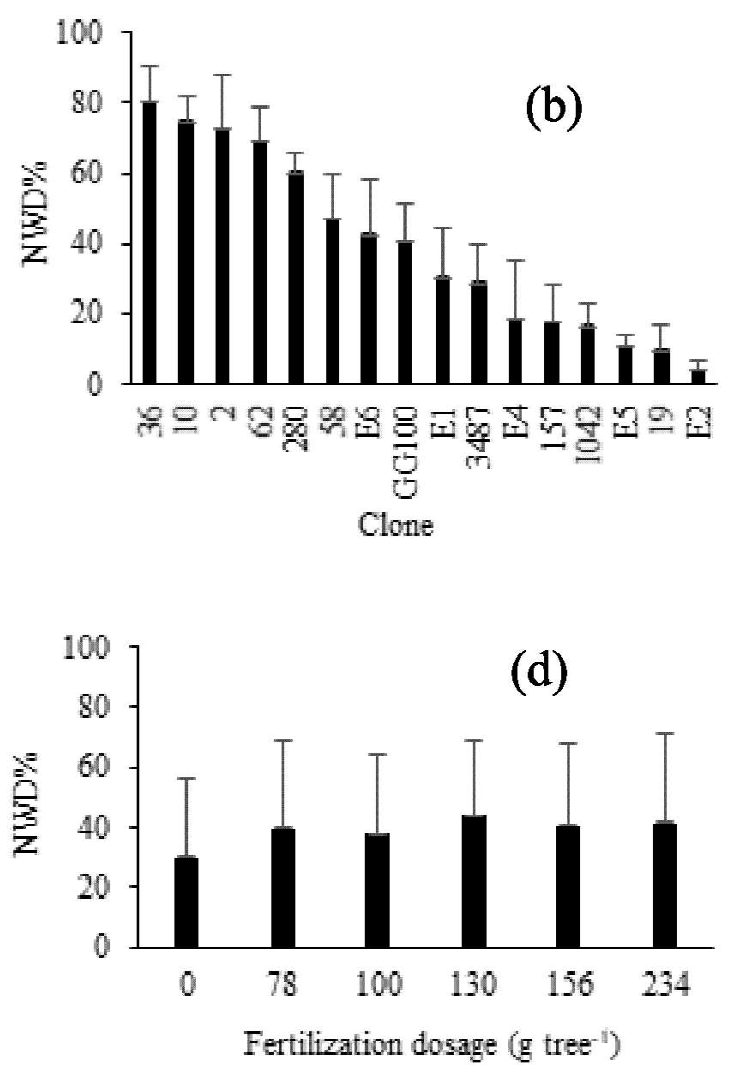

Figure 1 - Proportion of total tree height with dieback symptoms (HWD\%) (a,c) and proportion of trees with dieback $(\mathrm{NWD} \%)(\mathrm{b}, \mathrm{d})$, at 13 months after planting (end of the first dry season), as a function of clones (a,b) and fertilization levels (c,d), in Vazante, MG. Crown damage refers to leaf senescence and branch death

Figura 1 - Proporção da altura da árvore (a,c) e proporção do número de árvores $(b, d)$, com sintomas de seca de ponteiros, aos 13 meses de idade, em função do clone $(a, b)$ e da adubação $(c, d)$, em Vazante, MG. Os danos à copa se referem à senescência de folhas e morte de galhos

Revista Árvore. 2017;41(3):e410309 
58, E6 and E1 (Table 2). Clone 58 showed HWD\% greater than $5 \%$ with the application of 78 and 130 g plant $^{-1}$ NPK. The E6 and E1 clones showed values higher than $5 \%$ only with the application of 130 and $156 \mathrm{~g}$ plant $^{-1}$, respectively. The control, with the application of reactive rock phosphate alone, showed a low value of HWD\%, especially for the E6 and E1 clones.

The LAI at the age of 13 and 21 months varied only between the clones $(\mathrm{p}<0.05)$. At 13 months (November 2007), after the first dry season, the clones E5, E1, 157, E6 and E4 showed the highest LAI(Table 3). At this age, there was an inverse relationship between LAI and dieback. For example, the clone E5 showed a lower incidence of dieback, both regarding to HWD\% $(0.85 \%)$ and PWD\% (11\%) (Figure 1), and exhibited the greatest LAI (1.56). Clones 62, 58, 10 and 280 presented the lowest values of LAI and the highest dieback intensity.

At 21 months (July 2008), after the second rainy season, the clones 19, I042, 2, GG100 and 280 increased their position in relation to LAI at 13 months. Noteworthy is the change of the clone 2 (from 12th to 4 th position) and GG100 (from the 11th to 5th position). On the other hand, the clones E5, E1, E4 and 157, which were among the five with the highest LAI at 11 months showed drastic reduction in their positions, at 21 months.

The following equations for volume with bark were obtained for six clones, based on the inventory for the commercial plantations of the VS company: GG100: $V w b=0,0000347095 d b h^{1,583373} H t^{1,381895} ;$ I042: $V w b$ $=0,0000677747 d b h^{1,665882} H t^{1,0881426} ; 19: V w b=$ $0,0000806560 d b h^{1,813596} H t^{0,887406} ; 58: V w b=$ $0,0000185002 d b h^{1,551779} H t^{1,652543} ; 62: V w b=$ $0,0000786025 d b h^{1,772312} H t^{0,909757} ; 2: V w b=$ $0,0000453973 d b h^{1,646645} H t^{1,249505}$. The general equation to estimate the volume with bark of other clones that are not in the commercial plantations was: $V w b=$ $0.0000446713 * d a p^{1,611160 *} H t^{1,274887}$ where $V w b=$ volume of wood with bark $\left(\mathrm{m}^{3} \mathrm{ha}^{-1}\right), d b h=\operatorname{diameter}(\mathrm{cm})$ at $1.30 \mathrm{~m}$ and, $H t=$ total height of the tree $(\mathrm{m})$.

The yield varied $(\mathrm{p}<0.05)$ among clones and fertilizer levels, and there was no significant effect for the interaction clone $x$ fertilizer levels $(p>0.05)$, at 11 , 19 and 25 months of age. At 11 months (September), at the end of the first dry season, the E1 clone (group a) was the most productive $\left(6.1 \mathrm{~m}^{3} \mathrm{ha}^{-1}\right)(\mathrm{p}<0.05)$, followed
Table 2 - Proportion of total tree height with dieback symptoms (HWD\%) of eucalypt clones at 13 months after planting (end of the first dry season), for different fertilizer levels, for the clones 58, E6 and E1, in Vazante, MG.

Tabela 2 - Proporção da altura da árvore afetada com os sintomas de seca de ponteiros (HSP) na idade de 13 meses, por nivel de adubação, para os clones 58, E6 e E1, em Vazante, $M G$.

\begin{tabular}{|c|c|c|c|c|c|}
\hline \multicolumn{2}{|c|}{ Clone 58} & \multicolumn{2}{|c|}{ Clone E6 } & \multicolumn{2}{|c|}{ Clone E1 } \\
\hline $\begin{array}{l}\text { Fertilizer } \\
\left(\text { g plant }^{-1}\right)\end{array}$ & HWD\% & $\begin{array}{l}\text { Fertilizer } \\
\left(\text { g plant }^{-1}\right)\end{array}$ & HWD\% & $\begin{array}{l}\text { Fertilizer } \\
\left(\text { g plant }^{-1}\right)\end{array}$ & HWD $\%$ \\
\hline 130 & $7.90 \mathrm{a}$ & 130 & $5.96 a$ & 156 & $6.16 \mathrm{a}$ \\
\hline 100 & $5.49 \mathrm{ab}$ & 156 & $2.15 \mathrm{~b}$ & 100 & $2.81 \mathrm{ab}$ \\
\hline 78 & $5.48 \mathrm{ab}$ & 234 & $2.00 \mathrm{~b}$ & 78 & $2.81 \mathrm{ab}$ \\
\hline 0 & $4.26 \mathrm{bc}$ & 78 & $1.98 \mathrm{~b}$ & 130 & $2.10 \mathrm{~b}$ \\
\hline 156 & $3.54 \mathrm{bc}$ & 0 & $1.58 \mathrm{~b}$ & 234 & $1.86 \mathrm{~b}$ \\
\hline 234 & $1.82 \mathrm{c}$ & 100 & $1.41 \mathrm{~b}$ & 0 & $1.49 \mathrm{~b}$ \\
\hline
\end{tabular}

Averages followed by the same letters, in each column, do not differ by the test of Tukey $(\mathrm{p}>0.05)$

Table 3 - Leaf area index (LAI) of eucalypt clones stands, aged 13 and 21 months, in the savannah region, Brazil.

Tabela 3 - Índice de área foliar em povoamentos de clones de eucalipto, aos 13 e 21 meses de idade, na região de cerrado, Brasil.

\begin{tabular}{|c|c|c|c|c|}
\hline \multicolumn{2}{|c|}{$\begin{array}{l}13 \text { months } \\
\text { (Nov./2007) }\end{array}$} & \multicolumn{3}{|c|}{$\begin{array}{l}21 \text { months } \\
\text { (July/2008) }\end{array}$} \\
\hline Clone & LAI & Clone & LAI & \\
\hline E5 & $1.56 \mathrm{a}$ & 19 & $3.48 \mathrm{a}$ & \\
\hline E 1 & $1.54 \mathrm{a}$ & E6 & $3.40 \mathrm{a}$ & \\
\hline 157 & $1.50 \mathrm{a}$ & I042 & $3.32 \mathrm{a}$ & \\
\hline E6 & $1.36 \mathrm{a}$ & 2 & $3.13 \mathrm{~b}$ & \\
\hline E4 & $1.34 \mathrm{a}$ & GG100 & $3.09 \mathrm{~b}$ & \\
\hline 19 & $1.26 \mathrm{~b}$ & E2 & $3.06 \mathrm{~b}$ & \\
\hline E2 & $1.25 \mathrm{~b}$ & 280 & 2.86 & $\mathrm{c}$ \\
\hline I042 & $1.17 \mathrm{~b}$ & E 1 & 2.77 & $\mathrm{c}$ \\
\hline 36 & $1.11 \mathrm{~b}$ & 3487 & 2.75 & $\mathrm{c}$ \\
\hline 3487 & $1.08 \mathrm{~b}$ & E5 & 2.61 & d \\
\hline GG100 & $1.07 \mathrm{~b}$ & 36 & 2.54 & d \\
\hline 2 & $1.04 \mathrm{~b}$ & 157 & 2.54 & d \\
\hline 280 & $0.93 \mathrm{c}$ & 58 & 2.49 & d \\
\hline 10 & $0.70 \mathrm{c}$ & E4 & 2.47 & d \\
\hline 58 & $0.68 \mathrm{c}$ & 62 & 2.43 & d \\
\hline 62 & $0.61 \mathrm{c}$ & 10 & 2.31 & d \\
\hline
\end{tabular}

Averages followed by the same letters, in each column, do not differ by the test of Scott Knott ( $p>0.05)$

by the clones E4, I042, 3487 and 157 (group b), which were equal among themselves $(\mathrm{p}<0.05)$ (Table 4). Between the ages of 11 to 19 months and 19 to 25 months there have been changes in the positions of clones as related to their yield, except for the clone E1, which 
remained in first place in all ages, although there was substantial reduction in LAI at 21 months. In the group $\mathrm{b}$, the E4 and $\mathrm{I042}$ clones fell from the 2 nd and $3 \mathrm{rd}$ positions, at 11 months, to the 6 th and 7 th positions, respectively, at 19 months, but remained among the six most productive at 25 months. The biggest change of position occurred for the clone 19 , which continually rose from 10 th ( 11 months) to the 2 nd position ( 25 months).

The least productive clones at 11 months of age were $58\left(1.8 \mathrm{~m}^{3} \mathrm{ha}^{-1}\right), 280\left(2.2 \mathrm{~m}^{3} \mathrm{ha}^{-1}\right)$ and $36\left(2.5 \mathrm{~m}^{3}\right.$ $\mathrm{ha}^{-1}$ ) (Table 4) which, together with the clones E6, 10, 62 and 2 formed the group with the lowest production at 25 months.

There was a strong positive correlation $(\mathrm{p}<0.001)$ between LAI at 13 months and PMI between 0 and 11 months $(\mathrm{r}=0.555)$ and, also, with PMI between 11 and 19 months $(\mathrm{r}=0.446)$. LAI at 21 months was positively correlated $(\mathrm{p}=0.04)$ with PMI between 0 and 11 months $(r=0.491)$. No significant correlation was observed between LAI in both ages with PMI between 19 and 25 months.

\section{DISCUSSION}

There was a large difference in the dieback intensity. The greatest intensity of eucalypt dieback has mainly been reported in young stands. According to Ferreira (1989), the Vale do Rio Doce dieback is more pronounced until the age of 1.5 years. In the present study, the evaluation of dieback symptoms was performed at 13 months of age, after the first dry season. At this age it was observed high dieback intensity for some genotypes and an inverse relationship between LAI and dieback. This experiment was established in October 2006 and in that year the soil water deficit based on the Thornthwaite method reached only $221 \mathrm{~mm}$, while in the year 2007 this deficit reached $508 \mathrm{~mm}$, with a dry period of eight months. In this situation, plant water stress has to be considered the major cause of the dieback. Soil water-logging, associated with manganese levels and reduced oxygen, has been reported as a major cause of eucalypt dieback in the Rio Doce region, Brazil, where the soil conditions are different from the savannah region (Harguindeguy, 2013; Leite et al., 2014). As the soil of the study area is classified as well drained soil (sand clay loam), and there was a long period with water deficit before dieback evaluation, soil water-logging cannot be the cause of this dieback.

Table 4 - Average yield $\left(\mathrm{m}^{3} \mathrm{ha}^{-1}\right)$, periodic monthly increment (PMI), in $\mathrm{m}^{3} \mathrm{ha}^{-1} \mathrm{month}^{-1}$, and mean monthly increment (MMI), in $\mathrm{m}^{3} \mathrm{ha}^{-1} \mathrm{month}^{-1}$ of eucalypt clones stands, aged 11 to 25 months, in the savannah region, Brazil.

Tabela 4 - Produção $\left(\mathrm{m}^{3} h \mathrm{~h}^{-1}\right)$, incremento periódico mensal $\left(\mathrm{m}^{3} h \mathrm{~h}^{-1}\right.$ mês $\left.\mathrm{s}^{-1}\right)$, e incremento médio mensal $\left(\mathrm{m}^{3} h \mathrm{~h}^{-1} \mathrm{mê}^{-1}\right)$ em povoamento de clones de eucalipto, com 11 a 25 meses de idade, na região de cerrado, Brasil.

\begin{tabular}{|c|c|c|c|c|c|c|c|c|c|c|c|c|}
\hline \multicolumn{3}{|c|}{11 months (Sept/ 2007) } & \multicolumn{5}{|c|}{19 months (May/2008) } & \multicolumn{5}{|c|}{25 months (Nov/2008) } \\
\hline Clone & $\begin{array}{l}\text { Volume } \\
\left(\mathrm{m}^{3} \mathrm{ha}^{-1}\right)\end{array}$ & $\begin{array}{c}\mathrm{PMI} / \mathrm{MMI} \\
\left(\mathrm{m}^{3} \mathrm{ha}^{-1}\right. \\
\left.\mathrm{month}^{-1}\right)\end{array}$ & Clone & $\begin{array}{l}\text { Volum } \\
\left(\mathrm{m}^{3} \mathrm{ha}^{-1}\right.\end{array}$ & & $\begin{array}{c}\text { PMI } \\
\left(\mathrm{m}^{3} \mathrm{ha}^{-1}\right. \\
\left.\text { month }^{-1}\right)\end{array}$ & $\begin{array}{c}\text { MMI } \\
\left(\mathrm{m}^{3} \mathrm{ha}^{-1}\right. \\
\left.\text { month }^{-1}\right)\end{array}$ & Clone & $\begin{array}{l}\text { Volume } \\
\left(\mathrm{m}^{3} \mathrm{ha}^{-1}\right)\end{array}$ & & $\begin{array}{c}\text { PMI } \\
\left(\mathrm{m}^{3} \mathrm{ha}^{-1}\right. \\
\left.\text { month }^{-1}\right)\end{array}$ & $\begin{array}{c}\text { MMI } \\
\left(\mathrm{m}^{3} \mathrm{ha}^{-1}\right. \\
\left.\text { month }^{-1}\right) \\
\end{array}$ \\
\hline E1 & $6.13 a$ & 0.56 & E1 & $28.17 \mathrm{a}$ & & 2.75 & 1.48 & E1 & $37.01 \mathrm{a}$ & & 1.47 & 1.48 \\
\hline E4 & $5.03 \mathrm{~b}$ & 0.46 & 157 & 24.981 & & 2.56 & 1.31 & 19 & $36.02 \mathrm{a}$ & & 2.09 & 1.44 \\
\hline I042 & $4.71 \mathrm{~b}$ & 0.43 & 3487 & 23.601 & & 2.37 & 1.24 & 157 & $35.94 \mathrm{a}$ & & 1.83 & 1.44 \\
\hline 3487 & $4.60 \mathrm{~b}$ & 0.42 & 19 & 23.511 & & 2.57 & 1.24 & I042 & $35.69 \mathrm{a}$ & & 2.11 & 1.43 \\
\hline 157 & $4.48 \mathrm{~b}$ & 0.41 & E5 & 23.481 & & 2.43 & 1.24 & E5 & $35.30 \mathrm{a}$ & & 1.97 & 1.41 \\
\hline E5 & $4.04 \mathrm{c}$ & 0.37 & E4 & 23.111 & & 2.26 & 1.22 & E4 & $34.97 \mathrm{a}$ & & 1.98 & 1.40 \\
\hline GG100 & $3.74 \mathrm{c}$ & 0.34 & I042 & 23.021 & & 2.29 & 1.21 & 3487 & $34.97 \mathrm{a}$ & & 1.89 & 1.40 \\
\hline 62 & 3.26 & 0.30 & GG100 & 21.33 & $\mathrm{c}$ & 2.20 & 1.12 & GG100 & $33.01 \mathrm{~b}$ & & 1.95 & 1.32 \\
\hline 2 & 3.02 & 0.27 & E2 & 20.53 & $\mathrm{c}$ & 2.21 & 1.08 & E2 & 31.89 & $\mathrm{c}$ & 1.89 & 1.28 \\
\hline 19 & 2.95 & 0.27 & 36 & 17.59 & $\mathrm{~d}$ & 1.89 & 0.93 & 2 & 28.24 & $\mathrm{~d}$ & 2.10 & 1.13 \\
\hline 10 & 2.92 & 0.26 & 62 & 17.17 & d & 1.84 & 0.90 & 36 & 27.77 & $\mathrm{~d}$ & 1.70 & 1.11 \\
\hline E2 & 2.84 & 0.26 & 10 & 16.89 & d & 1.75 & 0.89 & 62 & 26.84 & $\mathrm{~d}$ & 1.61 & 1.07 \\
\hline E6 & 2.63 & 0.24 & 2 & 15.63 & d & 1.58 & 0.82 & 10 & 26.28 & $\mathrm{~d}$ & 1.57 & 1.05 \\
\hline 36 & 2.47 & 0.22 & 58 & 14.47 & $\mathrm{e}$ & 1.58 & 0.76 & 58 & 23.54 & e & 1.51 & 0.94 \\
\hline 280 & 2.17 & 0.20 & E6 & 13.92 & e & 1.41 & 0.73 & E6 & 23.42 & $\mathrm{e}$ & 1.58 & 0.94 \\
\hline 58 & 1.84 & 0.17 & 280 & 12.41 & $\mathrm{f}$ & 1.28 & 0.65 & 280 & 20.70 & $\mathrm{f}$ & 1.38 & 0.83 \\
\hline
\end{tabular}

Averages followed by the same letters, in each column, do not differ by the test of Scott Knott ( $p>0.05)$.

Revista Árvore. 2017;41(3):e410309 
The evaluation of eucalypt clones under soil water stress conditions is of great importance since most of the forest plantations in Brazil are established in a region with extended period of low soil water availability. Maschio et al. (2000) reported high dieback intensity of $E$. grandis related to high water deficit. The water deficit in the soil can promote dieback with different levels of severity, depending on the genotype, similarly to the results in this study. By analyzing the dieback data obtained after the first dry season, at the age of 13 months, it was found that the clones $36,62,10$, 280 and 58, originating from E. camaldulensis or $E$. camaldulensis x E. grandis, exhibited severe dieback symptoms in relation to the proportion of the plant height with dieback and to the proportion of trees with dieback. On the other hand, the other clones, originating from E. urophylla or E. urophylla x E. grandis, except the clone 2 , showed reduced dieback symptoms. Chaves et al. (2004) also reported that under water stress, in nursery conditions, the highest values of leaf abscission were observed for the clone of E. camaldulensis as compared to the clones of E. grandis $x$ E. urophylla. Gonçalves and Passos (2000) reported higher leaf abscission for E. camaldulensis than for Eucalyptus cloeziana, with water stress induction.

The loss of leaves in the trees as for the $E$. camaldulensis genotypes is considered one of the plant adaptations to enable their survival even in conditions of severe soil water deficiency (Pook, 1985). One relevant characteristic of the plant that exhibit loss of leaves is related to the capacity to recover plant water status and to produce new leaves with increasing water availability. Fernandes (2012) found that after re-irrigation the recovery of the water status of the E. urophylla $x$ E. camaldulensis clone was faster than for clones of E. urophyllax E. grandis and E. urophylla. Rapid recovery of water status and efficient production of new leaves were also reported by Chaves et al. (2004) for E. camaldulensis clone compared with other genotypes. Tatagiba et al. (2007) found different growth responses of eucalypt clones, after being subjected to severe water deficit in the soil, and two clones resumed, immediately, satisfactory growth after re-irrigation.

The species E. camaldulensis or their hybrids are considered more suited to water stress than many other eucalypt genotypes when looking at their ability of stomata closure to reduce water loss under water stress (Gomes, 1994; Leles et al., 1998). Gomes (1994) found the following sequence in relation to transpiration rate: E. camaldulensis $<$ E. urophylla $<$ E. pellita in the savannah region. Also, it should be noted that the root system of E. camaldulensis or their hybrids is usually deeper than for the other species, favoring the absorption of water at greater depths (Awe et al., 1976; Reis and Hall, 1987; Reis et al., 2006). This feature enhances the survival of plants in extreme conditions of water stress. According to Reis and Hall (1986), with water supplementation only to a small portion of $E$. camaldulensis roots, the pre-dawn water potential was similar to fully irrigated plants, justifying the choice of genotypes with deeper roots to access moisture soil at greater depths.

The availability of nutrients in the soil and its acquisition by plants can interfere with the intensity of leaf senescence when plants are subjected to drought stress (Oliva et al., 1989; Gonçalves and Passos, 2000). In the present study, the dieback intensity was lower when there was only natural rock phosphate application. Oliva et al. (1989) observed higher dieback in $E$. camaldulensis plants under higher level of phosphorus fertilization. Gonçalves and Passos (2000) reported that E. camaldulensis showed higher root/shoot ratio and a smaller reduction of shoot growth with increased water stress and reduced level of phosphorus in the soil as compared to other species studied. Reis et al. (1985) observed higher biomass allocation to roots in low fertility soils in relation to higher fertility soils. As the shoot growth rate is reduced under these conditions, the leaf area production is reduced. Higher root/shoot ratio and lower leaf production favor the uptake of water and nutrients and reduces the loss of water, keeping more adequate water status, which may explain the smaller effect of water stress on the leaf abscission under low fertility. These results indicate that the application of high doses of fertilizers can provide increased productivity of eucalypt plantations, however, with the occurrence of water deficiency, it can favor the dieback due to high plant water loss leaf area. In the present study there was interaction between fertilizer levels and proportion of plant height with dieback for three clones, among 16 studied. This indicate that dieback observed in the present study may not be well explained based on the fertilizer levels applied.

The effect of each nutrient in relation to leaf senescence under water stress conditions should be studied separately as they have different function in

Revista Árvore. 2017;41(3):e410309 
the plant. For example, the relationship between the availability of boron and the eucalypt dieback in the dry season, especially in the savannah region, characterized by low levels of boron, is of great importance. According to Andrade et al. (1995), the $\mathrm{B}$ requirement of $E$. camaldulensis provenances was smaller but there was more intense apical death when B was omitted, followed by E. urophylla, Eucalyptus dunnii and Eucalyptus globulus. Ramos et al. (2009) reported quadratic effect of B on the growth of $E$. citriodora seedlings, showing that the boron in the soil was too low. The authors observed that the effect of soil type and water stress on dieback was independent of B level. Boron was applied twice to all treatments in the present study.

There was a great variation in LAI among the clones ( 0.61 to 1.56 at 13 months of age) due to the differences in genetic material background. Fontan (2007) noted that E. urophylla clone presented LAI greater than E. camaldulensis clone because the latter one is characterized by hanging branches and leaves. Gonçalves and Passos (2000) also found significant differences in leaf area between eucalypt genotypes under different fertilizer levels and soil water availability.

The highest values of LAI at 13 months of age were observed for the E5 clone, followed by the E1, 157, E6 and E4 ones. This high LAI could indicate high yield potential, especially considering that these clones had also reduced dieback intensity at 13 months of age. It is noted, however, that other genetic or environmental factors may be affecting yield as the clone E6 is among the least productive up to the age of 25 months. It is likely that the arrangement of the leaves and branches of this clone may be promoting intense crown self-shading, reducing carbon fixation efficiency. Wong and Dunin (1987) reported that the lower third of the living tree canopy in eucalypt forest, in Australia, contributed only with $20.74 \%$ of the total carbon accumulated by the canopy. Besides the effect on carbon fixation effectiveness, the high proportion of senescent leaves promotes water loss due to their limited control of leaf stomata closure.

There was a great change in LAI between 13 and 21 months. The high values of LAI of clones 19 and I042, at 21 months, as compared to 13 months, can be explained by the low intensity of dieback of these clones, at 13 months. The position of the E1 clone as related to the LAI was reduced from second to eighth at the age of 21 months, possibly due to leaves selfshading, which stimulated leaf abscission. It is likely that higher yield can be obtained for this clone if established at wider tree planting spatial arrangements, allowing a better distribution of the radiation incidence on the leaves throughout the canopy (Paula et al., 2013; Oliveira et al., 2016). As reported by Oliveira et al. (2016) LAI decreased for most eucalypt clones studied with the increase in tree density.

The resilience of different genetic materials after drought can be analyzed to subsidize the selection of the best materials for such conditions with a period of low availability of water. There was a large difference in the dieback intensity and yield for the studied eucalypt clones. This difference in yield among clones is related to their genetic load and the efficiency in the use of the growth resources available to the plant, since it has been verified high genotype $\mathrm{x}$ environment interaction for eucalypt (Santos et al., 2015).

Clone E1 showed the highest yield among all clones at the age of 19 months, even after a prolonged dry period, with relatively low values of dieback. Thus, this clone could be considered for planting in areas with high water deficit, for the production of wood for energy, in short rotation.

The correlation between the PMI at the age up to 11 and between 11 and 19 months was significant only for the LAI at 13 months. This indicates that before the canopy closure, the yield is directly related to the leaf area. After canopy closure, the most productive clones with high values of LAI may present intense leaf abscission. Thus, the variation in the LAI does not necessarily imply increase in yield. If the highest LAI values are associated with higher leaf senescence rate, its contribution to recover the water status of the plant is limited, predisposing plants to dieback. The formation of the crown of a tree is very dynamic, varying in short time, as reported by Lima (2003), requiring assessments of both the LAI and yield at shorter intervals to allow more precise analysis of the relationship between LAI and leaf production in different environmental conditions. According to Linares and Camarero (2012) growth reduction occurs even before defoliation and short interval assessments would be helpful to understand plant growth dynamics.

Revista Árvore. 2017;41(3):e410309 


\section{CONCLUSIONS}

The evaluation of eucalypt genotypes dieback after water stress period is of great importance since most of the plantations in Brazil have been established in areas with periods of low soil water availability. It was observed large variation among eucalypt genotypes regarding to the dieback at the end of the first dry season, leaf area index and yield. Several clones exhibited very high values of dieback symptoms after the first dry season, when the soil water deficit reached 508 $\mathrm{mm}$ in the year, indicating that water deficit is a major limiting factor for their growth in that region. The interaction between dieback and fertilizer levels was observed only for three clones. The leaf area index at 13 months, before canopy closure, was positively correlated with the periodic monthly increment at earlier ages. The clones E2, E4, 19, E5, I042 and 157 showed the lowest proportion of plant height with dieback and proportion of trees with dieback after a dry period and, they remained among the most productive ones up to the age of 25 months. Based on these results the clones above mentioned can be recommended aiming to obtain higher eucalypt yield at sites with soil water shortage. The clone E1, with medium sensitivity to dieback, is the most productive one up to the age of 25 months, and should also be considered for planting in specific sites.

\section{ACKNOWLEDGEMENTS}

The authors thank the Conselho Nacional de Desenvolvimento Científico e Tecnológico (CNPq), the Fundação de Amparo à Pesquisa do Estado de Minas Gerais (FAPEMIG), the Universidade Federal de Viçosa (UFV), and the Votorantim Siderurgia S. A. for providing the financial support, the experimental area and, the logistic for data collection.

\section{REFERENCES}

Almeida AQ, Ribeiro A, Leite FP. Relação entre a seca dos ponteiros do eucalipto e o clima no vale da bacia hidrográfica do Rio Doce. Engenharia Ambiental. 2013;10:5-13.

Andrade IG. Marcadores anatômicos do lenho associados à tolerância à seca de ponteiros em Eucalyptus (Myrtaceae) [dissertação] Viçosa, MG:
Universidade Federal de Viçosa; 2013.

Andrade SC, Barros NF, Novais RF, Teixeira JL, Leal GL. Exigencia y distribución de boro en plantas de eucalipto. Bosque. 1995;16(1):53-9.

Arriel DAA, Fonseca NR, Guimarães LMS, Hermenegildo PS, Mafia RG, Borges Júnior N et al. Wilt and die-back of Eucalyptus spp. caused by Erwinia psidii in Brazil. Forest Pathology. 2014;44:255-65.

Awe JO, Shepherd KR, Florence RG. Root development in provenances of Eucalyptus camaldulensis Dehn. Australian Forestry. 1976;85:201-9.

Barros NF, Neves JCL, Novais RF. Recomendação de fertilizantes minerais em plantios de eucalipto. In: Gonçalves JLM, Benedetti V editores. Nutrição e fertilização florestal. Piracicaba: IPEF; 2000. p.269-86.

Binkley D, Stape JL, Ryan MGT. Thinking about efficiency of resource use in forests. Forest Ecology and Management. 2004;193:5-16.

Bouillet JP, Laclau JP, Arnaud M, M'Bou AT, Saint-André L, Jourdan C. Changes with age in the spatial distribution of roots of Eucalyptus clone in Congo: Impact on water and nutrient uptake. Forest Ecology and Management. 2002;171:43-57.

Broeckx LS, Vanbeveren SPP, Verlinden MS, Ceulemans R. First vs. second rotation of a poplar short rotation coppice: leaf area development, light interception and radiation use efficiency. iForest (early view): e1-e9. [accessed on: 08 Set. 2015.

Chaves JH, Reis GG, Reis MGF, Neves JCL, Pezzopane JEM, Polli HQ. Seleção precoce de clones de eucalipto para ambientes com disponibilidade diferenciada de água no solo: relações hídricas de plantas em tubetes. Revista Árvore. 2004;28(3):333-41.

Chaves RA, Reis MGF, Reis GG, Pezzopane JEM, Xavier A, Monte MA. Dinâmica de cobertura de dossel de povoamentos de clone de Eucalyptus grandis W. Hill ex-Maiden submetidos a desrama artificial e desbaste. Revista Árvore. 2007;31(6):989-98. 
Cipriani HN, Vieira AH, Mendes AM, Marcolan AL. Seca de ponteiros do eucalipto em Rondônia: considerações sobre a escolha de clones para o Estado. Porto Velho: Embrapa Rondônia; 2012. (Comunicado técnico, 378)

Coutinho TA, Preisig O, Mergaert J, Cnockaert MC, Riedel K-H, Swings J et al. Bacterial blight and dieback of Eucalyptus species, hybrids, and clones in South Africa. Plant Disease. 2002;86:20-5.

Fernandes ET. Fotossíntese e crescimento inicial de clones de eucalipto sob diferentes regimes hídricos [dissertação]. Vitória da Conquista: Universidade Estadual do Sudoeste da Bahia; 2012.

Ferreira FA. Patologia florestal: principais doenças florestais no Brasil. Viçosa, MG: SIF; 1989. 570p.

Fontan ICI. Dinâmica de copa e crescimento de clones de eucalipto submetidos a desrama em sistema agroflorestal [dissertação]. Viçosa, MG: Universidade Federal de Viçosa; 2007.

Gonçalves JLM, Stape JL, Laclau JP, Smethurst P, Gava JL. Silvicultural effects on the productivity and wood quality of eucalypt plantations. Forest Ecology and Management. 2004;193:45-61.

Gonçalves MR, Passos CAM. Crescimento de cinco espécies de eucalipto submetidas a déficit hídrico em dois níveis de fósforo. Ciência Florestal. 2000;10(2):145-61. http://dx.doi.org/ $\underline{10.1016 / j . f o r e c o .2004 .01 .02}$

Gomes RT. Efeito do espaçamento no crescimento e relações hídricas de Eucalytpus spp na região de cerrado de Minas Gerais. Viçosa, MG: Universidade Federal de Viçosa; 1994.

Harguindeguy I. Respostas fisiológicas à hipóxia e a manganês em clones de eucalipto com tolerância diferencial à seca de ponteiros do Vale do Rio Doce [dissertação]. Viçosa, MG: Universidade Federal de Viçosa; 2013.

Lang ARG, Mcmurtrie RE. Total leaf area of single trees of Eucalyptus grandis estimated from transmittances of the sun's beam. Agricultural and Forest Meteorology. 1992;58:79-92.
Leite FP, Novais RF, Silva IR, Barros NF, Neves JCL, Medeiros AGB et al. Acúmulo de manganês em plantios de eucalipto e sua relação com a "seca de ponteiros do eucalipto do Vale do Rio Doce. Revista Brasileira Ciência do Solo. 2014;38(1):193-204.

Leles PSS, Reis GG, Reis MGF, Morais EJ. Relações hídricas e crescimento de árvores de Eucalyptus camaldulensis e Eucalyptus pelitta sob diferentes espaçamentos na região de cerrado. Revista Árvore. 1998;22:41-50.

Lima APL. Aplicação de desrama em clone de Eucalyptus grandis em diferentes épocas e intensidade: efeitos sobre o crescimento e a dinâmica de copa e o tempo de desrama [tese]. Viçosa, MG: Universidade Federal de Viçosa; 2003.

Linares JC, Camarero JJ. Growth patterns and sensitivity to climate predict silver fir decline in the Spanish Pyrenees. European Journal of Forest Research. 2012;131:1001-12.

Maschio LMA, Andrade FM, Auer CG. Contribuição de fatores climáticos na ocorrência da seca de ponteiros de Eucalyptus grandis em Arapoti-PR. Boletim de Pesquisa Florestal. 2000;41:55-63.

Mattiello EM, Ruiz HA, Silva IR, Barros NF, Neves JCL, Behling M. Transporte de boro no solo e sua absorção por eucalipto. Revista Brasileira de Ciência do Solo. 2009;33:1281-90.

Leite FP, Novais ROF, Silva IR, Barros NF, Neves JCL, Medeiros AAGB et al. Manganese accumulation and its relation to "eucalyptus shoot blight in the Vale do Rio Doce". Revista Brasileira de Ciência do Solo. 2014;38:193-204.

Oliva MA, Barros NF, Gomes MMS, Lopes NF. Seca de ponteiros em Eucalyptus camaldulensis Dehn em relação a estresse hídrico e nutrição mineral. Revista Árvore. 1989;13:19-33.

Oliveira CHR, Reis GG, Reis MGF, Xavier A, Stocks JJ. Área foliar e biomassa de plantas intactas e de brotações de plantas jovens de clone de eucalipto em sistemas agrossilvopastoris. Revista Árvore. 2008;32:59-68

Revista Árvore. 2017;41(3):e410309 
Oliveira CHR, Reis GG, Reis MGF, Leite HG, Souza FC, Faria RS et al. Dynamics of eucalypt clones canopy and Brachiaria brizantha production in silvopastoral systems with different spatial arrangements. Agroforest Systems.2016;90:1077-88.

Paula RR, Reis GG, Reis MGF, Oliveira Neto SN, Garcia HG, Melido RCN et al. Eucalypt growth in monoculture and silvopastoral systems with varied tree initial densities and spatial arrangements. Agroforest Systems. 2013;87:1295-307.

Pook EW. Canopy dynamics of Eucalyptus maculata Hook. III - Effects of drought. Australian Journal of Botany. 1985;33:65-79.

Ramos SJ, Faquin V, Ferrreira RMA, Araújo JL, Carvalho GC. Crescimento e teores de boro em plantas de eucalipto (Eucalyptus citriodora) cultivadas em dois Latossolos sob influência de doses de boro e disponibilidade de água. Revista Árvore. 2009;33:57-65.

Reis GG, Hall AE. Relações hídricas e atividade do sistema radicular em Eucalyptus camaldulensis Dehn. em condições de campo. Revista Árvore. 1987;11:43-55.

Reis GG, Hall AE. Respostas de brotações de Eucalyptus camaldulensis Dehn. submetidas a diferentes níveis de deficiência hídrica. Revista Árvore. 1986;10:16-26.

Reis GG, Reis MGF, Fontan ICI, Monte MA, Gomes AN, Oliveira CHR. Crescimento de raízes e da parte aérea de clones de híbridos de Eucalyptus grandis x Eucalyptus urophylla e de Eucalyptus camaldulensis $\mathrm{x}$ Eucalyptus $\mathrm{spp}$ submetidos a dois regimes de irrigação. Revista Árvore. 2006;30:921-31.

Reis MGF, Kimmins JP, Resende GC, Barros NF.
Acúmulo de biomassa em uma sequência de idade de Eucalyptus grandis plantado no cerrado em duas áreas com diferentes produtividades. Revista Árvore. 1985;101:149-62.

Santos GA, Resende MDV, Silva LD, Higa A, Assis TF. Interação genótipos $\mathrm{x}$ ambientes para produtividade de clones de Eucalyptus L'Hér no Estado do Rio Grande do Sul. Revista Árvore. 2015;39:81-91.

Stape JL, Binkley D, Ryan MGT. Eucalyptus production and supply, use and efficiency of use of water, light and nitrogen across a geographic gradient in Brazil. Forest Ecology and Management. 2004;193:17-31.

Stape JL, Binkley D, Ryan MG, Fonseca S, Loos RA, Takahashi EN et al. The Brazil Eucalyptus Potential Productivity Project: Influence of water, nutrients and stand uniformity on wood production. Forest Ecology and Management. 2010;359:1684-94.

Tatagiba SD, Pezzopane JEM, Reis EF. Relações hídricas e trocas gasosas na seleção precoce de clones de eucalipto para ambientes com diferenciada disponibilidade de água no solo. Floresta. 2007;38:387-400.

Whitehead D, Beadle CL. Physiological regulation of productivity and water use in Eucalyptus: a review. Forest Ecology and Management. 2004;193:113-40.

Wong SC, Dunin FX. Photosynthesis and transpiration of trees in a eucalypt forest stand: $\mathrm{CO}_{2}$, light and humidity responses. Australian Journal of Plant Physiology. 1987;14:619-32.

Xavier AD, Soares JV, Almeida AC. Variação do índice de área foliar em clones de eucalipto ao longo de seu ciclo de crescimento. Revista Árvore. 2002;26:421-7. 